\title{
Salvação em Zc 8, 1-8: leitura exegética a partir do cenário de Zc 7,4-14
}

Orientadora: Maria de Lourdes Corrêa Lima

Doutoranda: Jane Maria Furghestti Lima

Área de Concentração: Teologia Bíblica

Linha de Pesquisa: Análise e Interpretação de Textos do Antigo e Novo Testamento

Projeto de Pesquisa: Instituição e teologia no Antigo Testamento

A presente pesquisa tem como objetivo principal estudar a salvação em Zc 8,1-8, apresentando uma leitura exegética desta unidade a partir do cenário de Zc 7,4-14, e demonstrar as inter-relações entre as unidades, construindo uma nova compreensão de Zc 8,1-8 em relação a Zc 7,4-14. A pesquisa considera que embora os textos de Zc 8,1-8 e Zc 7,4-14 possam sugerir, a princípio, uma relação de oposição, existe uma coerência temática, que torna justificável a sequência das duas unidades. A partir desta compreensão a implícita conexão entre Zc 8,1-8 e Zc 7,4-14 explica as relações de tensão presentes nos dois textos. A compreensão conjunta das duas unidades também permite revelar um sentido temático-teológico que evidencia a dinâmica da salvação e repreensão de Deus diante do comportamento de seu povo.

Ambas as unidades textuais seguiram a mesma metodologia em suas etapas até o seu desenvolvimento final: os passos essenciais do Método Histórico Crítico, conjugando-os com a análise sincrônica dos textos em sua forma final e canônica.

As unidades de Zc 8,1-8 e Zc 7,4-14 quando estudadas em conjunto mostraram uma afinidade e um sentido teológico percebidos no agir divino diante da resposta da geração pré-exílica e também da comunidade do profeta, que parece repetir os padrões do passado. YHWH reprovou o povo da geração passada por seu comportamento inflexível e desobediente (Zc 7,4-14). Por sua vez, ele resgatará novos grupos de exilados, que formarão o novo povo de Deus, pelo comportamento justo e obediente às suas palavras $(\mathrm{Zc} 8,1-8)$.

Palavras-chave: Teologia Bíblica. Literatura profética. Livro de Zacarias. 